\title{
UPAYA PEMENUHAN KEBUTUHAN DASAR MANUSIA
}

\author{
Drs. Abdul Samad Asaf, M.M \\ Fakultas Ilmu Sosial Dan Ilmu Politik Universitas Mahendradatta - Denpasar \\ Email : Abdulsamad@gmail.com
}

\begin{abstract}
Abstrak : Kebutuhan dasar manusia adalah kebutuhan yang langsung mempengaruhi hidup matinya seseorang, sehingga perlu segera untuk dapat di penuhi kebutuhan terhadapnya. Kebutuhan dasar manusia di kelompokkan menjadi lima jenis yang pemenuhannya di lakukan secara berjenjang sehingga berbentuk pireamid. Artinya kebutuhan yang berada pada jenjang yang pertama perlu lebih dahulu sebelum seseorang meningkat memenuhi kebutuhan yang kedua dan seterusnya. Kebutuhan tersebut adalah kebutuhan fisik, kebutuhan rasa aman, kebutuhan sosial, kebutuhan pengakuan dan kebutuhan aktualisasi diri. Kebutahan manusia tidak mungkin dapat di capai tanpa upaya untuk memenuhinya, baik upaya tersebut di lakukan sendiri-sendiri maupun secara berkelompok. Pemenuhan kebutuhan dasar manusia di upayakan melalui berbagai kegiatan pembangunan yang di lakukan oleh pemerintah bersama masyarakat. Tulisan ini mengupas tentang lima jenjang pemenuhan kebutuhan dasar manusia serta kegiatan yang di lakukan pemerintah bersama masyarakat untuk memenuhi kebutuhan dasar dan semakin meningkatnya kesejahteraan masyarakat.
\end{abstract}

Kata kunci: pemenuhan kebutuhan dasar, mempengaruhi hidup matinya seseorang.

Abstract: Basic human needs are needs that directly affect one's life and death, so they need to be able to be fulfilled immediately. Basic human needs are grouped into five types of fulfillment which are carried out in stages so that it is in the form of a pireamid. This means that the needs that are at the first level need first before someone increases to meet the needs of the second and so on. These needs are physical needs, security needs, social needs, recognition needs and self-actualization needs. Human blindness is impossible to achieve without efforts to fulfill it, both efforts are carried out individually or in groups. The fulfillment of basic human needs is sought through various development activities carried out by the government together with the community. This paper explores the five levels of meeting basic human needs and the activities carried out by the government together with the community to meet basic needs and the increasing welfare of the community.

Keywords: fulfillment of basic needs, affect one's life and death.

\section{Pendahuluan.}

Dalam hidup manusia di dunia di liputi oleh berbagai kebutuhan untuk membuat hidupnya berarti dan menjadikannya sejahtera. Kebutuhan tersebut mempunyai sifat yang berbeda-beda. Ada kebutuhan yang dapat di tunda untuk memenuhinya ada kebutuhan yang harus segera pemenuhannya. Kebutuhan yang perlu segera di penuhi pemenuhannya seringkali di sebut sebagau kebutuhan dasar manusia. Kebutuhan dasar manusia adalah kebutuhan yang langsung mempengaruhi hidup matinya seseorang, sehingga perlu segera untuk dapat di penuhi kebutuhan terhadapnya. Kebutuhan dasar manusia itupun mempunyai corak yang berbeda-beda pula. Pada manusia yang hidup dalam lingkungan masyarakat sederhana, sudah barang tentu kehidupan dasarnya berbeda dengan manusia yang hidup dalam masyarakat yang sudah maju. Manusia yang hidup di kota berbeda corak kebutuhan dasarnya dengan kehidupan masyarakat yang tinggal di desa-desa yang terpencil.

Walaupun coraknya berbeda-beda, kebutuhan dasar manusia mempunyai ciri karakteristik yang sama. Oleh karena itu, menurut seorang ahli ilmu jiwa Amerika yang terkenal bernama Abraham Maslow, menyebutkan bahwa kebutuhan dasar manusia dapat di kelompokkan menjadi 5 jenis, yang pemenuhannya perlu di susun secara berjenjang menurut prioritas kekuatannya.

Dasar pemikiran teori kebutuhan Abraham Maslow adalah:

1. Bahwa kebutuhan manusia itu bertahap, dan membentuk suatu hiraki dari fisiologis rasa aman, kebutuhan sosial,harga diri, dan aktualisasi diri.

2. Bahwa manusia mempunyai kebutuhan yang berkelanjutan.

3. Bahwa kebutuhan manusia saling tergantung dan saling melengkapi 
4. Bahwa kebutuhan yang telah terpuaskan akan berhenti sebagai motivasi, dan di gantikan oleh kebutuhan berikutnya.

Maslow berpendapat bahwa kebutuhan yang berada pada jenjang yang pertama perlu lebih dahulu di penuhi sebelum seseorang meningkat memenuhi kebutuhan yang kedua selanjutnya akan menimbulkan kebutuhan untuk memenuhi kebutuhan yang lebih tinggi. Sehingga kebutuhan dasar manusia tersusun seperti bentuk piramida. Adapun piramida kebutuhan dasar manusia adalah sebagai berikut:

\section{Kebutuhan Fisik (Physiological needs)}

Menurut Maslow, kebutuhan dasar yang paling mendasar adalah kebutuhan fisik (Physiologis need). Kebutuhan fisik ini merupakan kebutuhan yang perlu segera di penuhi agar manusia dapat bertahan hidup dan yang di maksud dengan kebutuhan fisik adalah kebutuhan untuk makan,sandang, pemurumahan, dan lain-lain yang di perlukan untuk hidup jasmaninya.

\section{a) Kebutuhan rasa aman (safety needs).}

Kebutuhan dasar manusia yang kedua adalah kebutuhan akan keamanan (safety needs) kebutuhan akan keamanan ini hanya akan menjadi kebutuhan dasar apabila kebutuhan pertama sudah di penuhi. Manusia memerlukan keamanan dalam hidupnya. Untuk keperluan tersebut dapat di wujudkan dengan menjadi pengikut orang yang di anggap kuat atau menjadi anggota perkumpulan bela diri. Ada banyak ragamnya cara orang untuk memenuhi kebutuhan keamanannya, yang dapat di telusuri dalam kehidupan masyarakat.

\section{b) Kebutuhan sosial (social needs)}

Setelah kebutuhan tahap kedua ini di penuhi, barulah manusia memikirkan untuk memenuhi kebutuhan yang ketiga, yaitu kebutuhan untuk bermasyarakat (social needs). Seseorang merasa perlu bergabung dengan orang - orang lain untuk mengembangkan kehidupannya. Mereka kemudian bersedia untuk taat pada aturan yang di sepakati bersama, adanya pembagian kerja dan sebagainya. Perkawinan di pandang sebagai bentuk pemenuhan kebutuhan masyarakat.

\section{c) Kebutuhan Pengakuan (esteem needs)}

Setelah kebutuhan tahap ketiga di penuhi, maka seseorang akan meningkat pada kebutuhan tahap ke empat, yaitu kebutuhan untuk di hormati (Ego esteem). Seseorang ingin di hormati oleh orang lain. Dan biasanya seseorang di hormati atau di hargai karena kedudukan atau kemampuannya di dalam masyarakatnya.

\section{d) Kebutuhan aktualisdasi diri (self-} actualization needs).

Pada tahap akhir adalah kebutuhan untuk berbeda dengan orang lain dengan mengaktualisasi/menampakkan hal-hal yang ada pada dirinya.bagi seseorang pelukis dia menginginkan kesempatan untuk dapat melukiskan sesuai dengan jiwanya. Begitupula bagi seseorang yang mempunyai kemampuan atau hal-hal lain yang dapat menjadikan dirinya berbeda dari pada orang lain, mempunyai kebutuhan untuk dapat mengekspresikan dirinya dalam cipta karya dan kursanya. Kebutuhan dasar manusia dapat juga di bedakan menjadi kebutuhan materi dan spiritual, kebutuhan material adalah kebutuhan terhadap barang-barang adalah kebutuhan yang menyangkut kebutuhan jiwa, seperti agama, ilmu pengetahuan.

\section{Pembahasan}

\section{Upaya manusia memenuhi kebutuhannya.}

Kebutuhan manusia tidak mungkin dapat di capai tanpa dengan upaya untuk memenuhinya. Upaya tersebut di lakukan baik sendiri-sendiri maupun secara kelompok. Pada awal kehidupannya manusia dalam memenuhi kebutuhannya di lakukan dengan mengandalkan pada kemampuan dirinya sendiri.

Mereka mencari umbi-umbian atau berbagai binatang buruan untuk keperluan dirinya dan keluarganya. Ketika kebutuhan mereka masih terbatas, dalam memenuhi kebutuhan itu masih cukup di tangani oleh orang perorangan. Tetapi ketika kebutuhan itu makin meluas dan mempunyai berbagai cara 
untuk pemecahannya yang membutuhkan kerjasama yang rumit, maka dalam memenuhi kebutuhan dasar seseorang tidak mungkin hanya mengandalkan pada kemampuan dirinya sendiri. Mereka memerlukan adanya kerja sama yang luas. Oleh karena itu tumbuhlah organisasi kemasyarakatan untuk mengatur cara-cara pemenuhan kebutuhan tersebut. Di Indonesia hamper tidak ada seseorang manusia yang untuk memenuhi kebutuhan dasarnya hanya mengandalkan usahanya sendiri.

Dengan kenyataan, bagi manusia yang mempunyai pola kebutuhannya yang sederahan mereka hidup dalam pola organisasi masyarakat yang sederhana pula. Sedangkan manusia yang mempunyai pola kebutuhan yang rumit, biasanya hidup dalam pola masyarakat yang kompleks yang terdapat masyarakat yang sudah maju. Dengan demikian dapat ditarik kesimpulan bahwa pola kehidupan masyarakat dimana seseorang itu tinggal atau berada, dapat dapat mencerminkan tingkat dan ragam kebutuhan dasarnya. Pola kehidupan manusia banyak di pengaruhi oleh keadaan alam yang memberikan potensi bagi pepenuhan kebutuhan mereka. Bagai masyarakat yang hidup sepanjang aliran sungai mempunyai pola kebutuhan yang di pengaruhi oleh kehidupan ditepi sungai. Begitu pula bagi masyarakat yang hidup di daerah-daerah dataran yang subur mempunyai pola kehidupan yang berbeda dengan kebutuhan yang sesuai dengan potensi yang ada sekelilingnya.

Adanya alam itupun membatasi manusia untuk mengembakan pola kebutuhannya. Bagi masyarakat yang hidup di daerah yang kurang hujan, akan membiasakan dirinya untuk membatasi kebutuhan akan air bersih sesuai dengan sumber-sumber yang tersedia. Tidak mungkin seseorang hidup dalam masyarakat desa di Indonesia dengan penuh keikhlasan.

\section{Kemiskinan dan keterbelakangan.}

Dalam upaya pemenuhan kebutuhan dasar manusia atau masyarakat banyak di hadapkan pada berbagai masalah, karena untuk mendapatkan dengan mudah di capai tujuan tersebut pada beberapa faktor yang perlu di pertimbangkan atau perlu di persiapkan lebih dahulu antara lain:

a) Kondisi sumber daya alam

b) Kondisi sumber daya manusia

c) Aspek pemerintahan dan kelembagaan

d) Aspek tata kemasyarakatan dan pranata sosial

e) Aspek tata ruang, prasarana dan sarana dan sebagainya

Tidak terpenuhinya kebutuhan dasar manusia tersebut dapat menimbulkan apa yang di sebut kemiskinan atau keterbelakangan. Artinya dalam kenyataan hidup terdapat manusia atau sekumpulan manusia / masyarakat yang masih kekurangan,belum dapat memenuhi kebutuhan dasarnya dan ada pula sudah memenuhi. Oleh karena itu perlu di upayakan peningkatkan usaha pemenuhan kebutuhan manusia melalui meningkatkan pendapatan dalam rangka peningkatan kesejahteraan, yang berarti bebas dari kemiskinan dan keterbelakangan.

Manusia sebagai obyek dan sekaligus sebagai subyek pembangunan perlu disiapkan dan diolah dengan cara pemenuhan kebutuhan baik melalui upaya masyarakat sendiri maupun dengan bimbingan dan bantuan pemerintah. 7

\section{Kondisi Desa.}

Aspek-aspek pemberdayaan masyarakat desa seperti tata pemerintahan desanya, tata kemasyarakatan (penduduk) dan tata ruang fisik desa (wilayah) adalah merupakan unsur yang penting dalam upaya peningkatan pendapatan dan kesejahteraan masyarakat, yang harus di perhatikan dalam pemberdayaan masyarakat untuk menunjang pemenuhan kebutuhan dasar manusia atau masyarakat.

Secara umum dapat di kemukakan bahwa dalam penataan ruang pemukiman pedesaan dapat di jumpai masalah-masalah 
yang di perlu din perhatikan dan ditanggulangin di antaranya adalah:

1) Desa terpencil dan terisolir dari pusat-pusat pelayanan jasa, termasuk di dalamnya desadesa pantai dan desa-desa pedalaman juga desa perbatasan maupun desa kepulauan.

2) Desa yang berpenduduk padat dengan tenaga kerja yang besar melebihi daya tampung potensi desa yang bersangkutan.

3) Desa yang sangat kurang penduduknya dengan jumlah tenaga kerja yang terlalu sedikit sehingga membatasi kemampuan untuk mengembangkan potensi desanya.

4) Pemukiman desa yang berolakasi di kawasan-kawasan yang tidak sesuai untuk kawasan budidaya, sehingga membahayakan kelestarian sumber daya yang ada dalam rangka pembangunan secara berkelanjutan.

5) Desa- desa dengan pemilikan tanah oleh petani yang tidak mencukupi untuk mendukung perkembangan kehidupan secara layak.

6) Dalam bidang kelembaga masih di hadapi juga berbagai masalah. Hal ini di sebabkan karena lembaga - lembaga pemerintah desa yang ada belum semuanya berfungsi seperti yang di harapkan.

7) Lembaga pemberdayaan masyarakat (LPM) atau (LKMD). Sebagai wadah untuk menyampaikan penjelasan dan menampung aspirasi masyarakat desa perlu di tingkatkan kemampuannya,

Kondisi desa sebagaimana tersebut diatas dapat diartikan masih terdapatnya keterbelakangan desa dan masyarakatnya dengan indicator sebagai berikut:

a. Tingkat pengetahuan dan keterampilan penduduk dan pendapatan masyarakat rendah kurang gizi, kurang sehat makanan, kurang pendidikan dan kebutuhan kebutuhan sosial lainnya.

b. Masih terbatasnya jumlah dan mutu prasarana dan sarana yang menunjung berfungsinya lembaga pemerintah, lembaga kemasyarakatan serta kurangnya prasarana yang mampu menunjung kelancaran lalu lintas perekonomian masyarakat.

c. Kemampuan masyarakat untuk meningkatkan ekonomi desa masih terbatas terutama yang berhubungan dengan sumber daya alam dan sumber daya manusia menyebabkan rendahnya produktivitas dan pendapatan desa sehingga mempengaruhi kemampuan untuk mengembangkan potensi desanya.

d. Masih banyak desa - desa yang belum mengatur tata ruang desa yang dapat menunjang usaha ekonomi masyarakat dalam memanfaatkan sumber daya alam yang ada dalam rangka peningkatan penghidupan dan kehidupan pada khusunya dan menunjang pembangunan pada umumnya.

Di tinjau dai segi yuridis dan dari kemantapan pembangunan riil materiil desa maka dapat di bedakan kondisi desa sebagai berikut:

a. Desa yang sudah mantap, yang dapt berkembang dengan baik antara lain:

1) Secara definitive administrative.

2) Tata pemerintahan berfungsi.

3) Tata masyarakat fositif (social economics)

4) Pendapatan penduduk yang mantap.

5) Tata ruang fisik desa mendukung, seperti terdapat tata ruang desa yang tepat, prasarana dan sarana serta umum mendukung dsb.

b. Desa yang belum mantap, sulit berkembangan, banyak permasalahan antara lain:

1) Ada desa definitive administrative, belum/kurang berfungsi.

2) Kondisi masyarakat masih labil (social,economics dan budaya) terdapat banyak kekurangan baik karena kepadatan penduduk maupun kekurangan penduduk.

3) Kondisi tata ruang yang belum diatur dan belum banyak tersedia prasarana dan sarana desa yang mendukung kemajuan desa dan masyarakatnya.

\section{Pola Pemukiman Masyarakat Desa.}


Tata ruang desa yang perlu di soroti dalam penulisan ini diantaranya adalah:

a. Ruang perumahan, yaitu lingkungan tempat tinggal penduduk yang memerlukan suasana ketenangan, ketertiban dan kesegaran.

b. Ruang untuk berkaya, adalah tempat bekerjam berusaha baik yang bersifat sekunder maupun yang bersifat tersier seperti kegiatan kerajinan, pertukaran, kegiatan jasa dan lain-lain.

c. Ruang marga atau prasarana perhubungan, yakni ruang yang menghubungkan sumber daya alam dengan sumber daya manusia wilayah satu dengan yang lainnya serta hubungan dengan pusat - pusat pengembangan.

d. Ruang yang memungkinan penduduk untuk berkembang sebagai manusia seutuhnya yang tidak hanya memerlukan kebutuhan jasmani, tetapi juga kebutuhan yang bersifat hiburan, rekreasi dan kesenangan lainnya.

e. Ruang untuk sarana meliputi sarana peribadatan , kesehatan , kuburan , pendidikan dan lain - lain.

5. Program- program dalam rangka penunjang pemenuhan kebutuhan dasar manusdia.

Peranan pemerintah untuk mensejahterakan kehidupan masyarakat di wujudkan dalam bentuk program dan proyek berupa penyedian prasarana dan sarana baik yang bersifat ekonomis maupun non ekonomis. Pembangunan melalui pemberdayaan masyarakat desa merupakan upaya untuk meningkatkan kesejahteraan masyarakat. Sedangkan tolok ukur kesejahteraan masyarakat yang dapat terpenuhi baik material maupun spriritual.

Program pemberdayaan masyarakat desa perlu memberikan peluang kepada masyarakat yang beada di bawah untuk tumbuh dan mengambil bagiannya dalam proses pemberdayaan masyarakat di desa, hal ini menyangkut "partisiupasi aktif dari bawah ". Yang perlu ditingkatkan sehingga mereka dapat tumbuh dan berkembang secara mandiri dalam memenuhi kebutuhan mereka. Programprogram pemberdayan desa yang perlu di kembangkan secara partisipatif dalam rangka memenuhi kebutuhan dasar anggota masyarakatnya merupakan sasaran terhadap masyarakat yang berada wilayah pedesaan.

a. Pemukiman desa yang sudah mantap.

b. Program pemberdayaan desa menunjung kebutuhan dasar bagi pemukiman yang sudah mantap antara lain adalah:

1) Pengembangan prasarana dan sarana desa

2) Pemugaran perumahan dan lingkungan desa.

c. Pemukiman desa yang belum mantap.

d. Program Pemberdayaan Desa penunjang kebutuhan Dasar Manusia bagi pemukiman yang belum mantap antara lain:

1) Daerah transmigrasi

2) Pemukiman kembali penduduk

3) Transmigrasi swakarsa Pengembangan Desa Potensia

4) Program pembangunan Kawasan Terpadu

a) Peningkatan/ pengembangan prasarana dan sarana berskala kecil, seperti jaringan irigasi, jalan, jembatan, demaga / pangkalan perahu, prasarana air bersih, pembangkit listrik, pasar, balai-balai pengobatan/penyuluhan keluarga berencana dan sebagainya.

b) Peningkatan produktivitas dengan mendukung peningkatan pendapatan melalui peningkatan tanaman pangan, perkebunan perternakan, perikanan perindustrian, peningkatan gizi dan kesehatan dsb.

c) Peningkatan kemampuan dan keterampilan sumber daya manusia dengan latihan keterampilan akan kegiatan produksi, kemasyarakatan maupun pemerintahan.

d) Penguatan kelembagaan dan pengembangan usaha ekonomi desa.

\section{Kesimpulan.}

Dengan demikian kebutuhan dasar manusia ternyata semakin berkembangan 
dengan semakin majunya kehidupan masyarakat. Kebutuhan dasar itu pemenuhannya di upayakan melalui berbagai kegiatan program pemberdayaan dari pemerintah bersama masyarakat. Kegiatan program pemberdayaan yang di laksanakan oleh pemerintah bersama dengan masyarakat di harapkan dapat mempercepat pencapaian kebutuhan dasar manusia Indonesia yang masih kurang, terutama yang tinggal di pedesaan terpencil. Semakin mudahnya pemenuhan kebutuhan dasar manusia dan semakin meningkatnya kesejahteraan masyarakat, maka di harapkan dengan program-program yang di laksanakan pemerintah dan masyarakat untuk berpartisipasi dalam pembangunan desanya, yang berarti turut serta mendorong mempercepat tingkat perkembangan desa yang lebih maju.

\section{DAFTAR PUSTAKA}

Ahmad toharadi,Ir,MM, Pemahaman Praktis Manajemen Sumber Daya Manusia,CV. Mandar Maju, Universitas Tanjungpura,2002.

Andre Bayo Ala, Drs, Kemiskinan dan Strategi Memerangi Kemiskinan,

Liberty, Yogyagkarta, 1996.
Buddy Prasardja, pembangunan Desa dan Masalah Kepemimpinannya, yayasan Ilmu-Ilmu Sosial, rajawali pers, 1986.

Djokosantoso Moeljono,Dr, Galang Tantangan SDM, Kepemimpinan dan

Prilaku Organisasi, PT. Elex Media Komputindo Kelompok Gramedia, Jakarta, 2002.

Kisdarto, Atmosoeprapto, Мепијu SDM Beerdaya, Dengan Kepemimpinan Efektif dan Manajemen Efisien, PT. Elex Media Komputindo Kelompok Gramedia, Jakarta, 2002.

Mukijat, Drs, Manajemen Sumber Daya Manusia, CV. Mandar maju, Bandung, 1999.

Mariot Tua Efendi Hariandja, Drs.,M.si, Manajemen Sumber Daya Manusia, Pandangan, Pengembangan, Pengkompensasian, dan Peningkatan Produktivitas Pegawai, PT. Grasindo, Jakarta, 2002.

Eka Nuraini Rachmawati, SE, Msi, Paradikma Baru Manajemen sumber Daya Manusia Sebagai Basis Meraih Keunggulan Kompetitif, Ekonisa Kampus Fakultas Ekonomi UII, Yogyagkarta, 2004.

Sodang P.Siagian, MPA, DR, Prof, Manajemen Sumber daya manusia, Bumi Aksara, 1995.

Yun Iswanto, Manajemen Sumber Daya Manusia, Universitas Terbuka, Jakarta, 2007. 